\title{
A Note About the Authors
}

Milton Silverman, Ph.D., born in San Francisco in 1910, was trained in biochemistry and pharmacology at Stanford University and the University of California School of Medicine.

From 1934 to 1959, he won national recognition as the science editor of the San Francisco Cbronicle, and later as a science writer for the Saturday Evening Post, Collier's, Reader's Digest, and other magazines. He is the author of Magic in a Bottle, a history of drug discovery, and he is a past president of the National Association of Science Writers, and a winner of the Lasker Award for distinguished medical reporting.

His own research has included studies on synthetic sugars, anesthetics, the pharmacology of alcoholic beverages, and cultural drinking patterns in Italy, Brazil, France, Sweden, and the United States.

He served as a special assistant to Dr. Lee in Washington from 1966 to 1969, and again at the University of California; San Francisco, from 1969 to 1972 . He is now a research pharmacologist at UCSFs School of Medicine, a lecturer at the Stanford University School of Medicine, and a consultant to the Food and Drug Administration.

Philip R. Lee, M.D., a member of a noted California medical family, was born in San Francisco in 1924. He was trained at Stanford University, the New York University-Bellevue Medical Center, and the Mayo Clinic. 
He joined the staff of the Palo Alto Medical Clinic in 1956, working primarily as a family physician. From 1963 to 1965 , he was the director of health services in the Agency for International Development; and from 1965 to 1969, he was the Assistant Secretary for Health and Scientific Affairs in the U.S. Department of Health, Education, and Welfare.

He served as chancellor of the University of California, San Francisco, from 1969 to 1972, and has been a professor of social medicine there since 1969.

His own studies have involved him in such fields as health manpower, health care for the elderly, bioethics, drug regulatory policies, and governmental health policies in general.

Mia Lydecker, born in The Hague, Holland, in 1926, was trained at the University of Utrecht, Louvain University, and the Sorbonne before coming to the United States. She began her career as a research associate with Dr. Silverman in 1962. During the past few years, she has worked with him in studying drug promotion and national drug insurance programs in Japan, Australia, New Zealand, Canada, and more than a score of other countries in Europe, Asia, and Africa.

During their years in Washington, Dr. Lee acted as chairman and Dr. Silverman as executive secretary and staff director of the HEW Task Force on Prescription Drugs. Ms. Lydecker served briefly as a consultant to the Task Force. The reports of this group in 1968 and 1969 led to significant changes in federal drug policies. That work also led to the publication in 1974 of Pills, Profits, and Politics by Drs. Silverman and Lee, which focused public attention on drug company policies and profits, as well as on the irrational prescribing and use of drugs. In turn, this led Drs. Silverman and Lee and Ms. Lydecker to the investigation of multinational drug company promotion in Latin America and the publication in 1976 of The Drugging of the Americas.

Dr. Lee is now director, Dr. Silverman a senior faculty member, and Ms. Lydecker a staff editor of UCSF's Health Policy Program. 